\title{
PENGEMBANGAN MEDIA BIG BOOK UNTUK MENSTIMULASI KEMAMPUAN MEMBACA PERMULAAN ANAK KELOMPOK B PAUD TANWIRUL QULUB TAHUN AJARAN 2016/2017
}

\author{
Fitriana Halimatussa'diyah \\ Fahruddin
}

\begin{abstract}
ABSTRAK
Penelitian ini dilatarbelakangi oleh kurang bervariasinya media pembelajaran yang digunakan di PAUD Tanwirul Qulub dalam menstimulasi kemampuan membaca permulaan anak. Tujuan penelitian ini adalah untuk menghasilkan media big book untuk menstimulasi kemampuan membaca permulaan anak kelompok B PAUD Tanwirul Qulub. Jenis penelitian ini adalah penelitian pengembangan dengan mengadopsi langkah-langkah penelitian dari Borg dan Gall yang disederhanakan menjadi empat tahap antara lain: tahap pengumpulan data, tahap perencanaan, tahap pengembangan, serta tahap validasi dan uji coba. Subjek penelitian ini adalah anak kelompok B3 PAUD Tanwirul Qulub yang berjumlah 15 orang. Hasil penelitian ini menunjukkan bahwa media big book yang dihasilkan dinyatakan layak digunakan dalam pembelajaran dengan persentase $82,5 \%$ berdasarkan uji produk oleh ahli dan kemampuan membaca permulaan anak mengalami peningkatan dengan persentase pada tahap pengembangan 1 sebesar 54,3\%, tahap pengembangan 2 sebesar 74,4\%, dan tahap pengembangan 3 sebesar 84,6\%. Berdasarkan hasil penelitian tersebut, dapat disimpulkan bahwa media big book yang dihasilkan dapat menstimulasi kemampuan membaca permulaan anak kelompok B PAUD Tanwirul Qulub Tahun Ajaran 2016/2017.
\end{abstract}

Kata Kunci: media big book, kemampuan membaca permulaan

\section{A. PENDAHULUAN}

Masa usia dini merupakan masa peletakan fondasi awal bagi pertumbuhan dan perkembangan anak. Apa yang diterima anak pada masa usia dini akan sangat berpengaruh terhadap pertumbuhan dan perkembangan anak selanjutnya. Untuk itu, penting bagi setiap anak untuk mendapatkan pendidikan dari sedini mungkin. Pendidikan anak usia dini mendasari jenjang pendidikan selanjutnya. Perkembangan secara optimal selama masa usia dini memiliki dampak terhadap pengembangan kemampuan untuk berbuat dan belajar pada masa-masa berikutnya. Sujiono (2009: 6) berpendapat bahwa anak usia dini adalah sosok individu yang sedang menjalani suatu proses perkembangan dengan pesat dan fundamental bagi kehidupan selanjutnya.

Mengingat besarnya potensi yang dimiliki anak pada masa usia dini, membaca merupakan salah satu kemampuan yang penting untuk dimiliki oleh anak, karena dengan membaca, anak akan lebih mudah mengetahui lebih banyak informasi dari berbagai sumber bacaan guna menambah pengetahuannya. Pengajaran membaca pada anak usia dini sampai saat ini masih menuai pro-kontra, banyak pihak yang menolak dengan alasan akan membebani anak, namun tidak sedikit pula yang menyarankan mengingat potensi yang dimiliki anak pada masa-masa awal kehidupannya. Terlepas dari pro-kontra tersebut, membaca sah-sah saja diperkenalkan pada anak usia dini, tentunya dengan cara-cara yang sesuai dengan pendekatan dan prinsip pembelajaran anak usia dini, sehingga anak menikmati proses pembelajaran dan tidak merasa terbebani.

Salah satu upaya dalam menciptakan pembelajaran yang menyenangkan bagi anak adalah dengan memilih media yang tepat untuk digunakan dalam pembelajaran. Media yang digunakan dalam pembelajaran anak usia dini harus memenuhi standar edukatif (pendidikan), standar teknik (langkah dan prosedur pembuatan), dan standar estetika (keindahan). 
Banyak media yang dapat digunakan dalam mengembangkan kemampuan membaca anak usia dini, antara lain kartu kata bergambar, majalah, video interaktif, big book, dan masih banyak lagi. Salah satu media yang dapat digunakan adalah big book. Menurut Solehuddin dkk (2009: 7), big book merupakan buku cerita yang berkarakteristik khusus yang dibesarkan baik teks maupun gambarnya sehingga memungkinkan terjadinya kegiatan membaca bersama antara guru dan murid. Buku ini memiliki karakteristik khusus seperti penuh warna-warni, memiliki kata yang dapat diulang-ulang, dan memiliki pola teks yang sederhana yang sesuai dengan kebutuhan dan perkembangan anak usia dini. Penggunaan big book secara tepat akan membantu guru dalam mengajarkan membaca pada anak usia dini dan akan membuat anak menikmati proses pembelajaran.

Berdasarkan observasi yang peneliti lakukan di PAUD Tanwirul Qulub, pembelajaran yang dilakukan terkait dengan stimulasi terhadap kemampuan membaca permulaan masih belum efektif yang menyebabkan belum optimalnya kemampuan membaca permulaan anak, hal tersebut terlihat pada saat proses pembelajaran anak masih belum bisa membedakan huruf dan belum mengetahui hubungan antara bunyi dan bentuk huruf. Dari 15 anak, hanya 2 anak yang sudah memiliki kemampuan membaca permulaan yang baik. Hal tersebut terjadi karena stimulasi dilakukan melalui pembelajaran secara langsung dengan meminta anak menyebutkan huruf yang terdapat di kartu huruf dan meminta anak untuk meniru kata di buku tulis yang disediakan, tanpa ada media-media yang mendukung, sehingga anak menjadi kurang tertarik dan termotivasi yang pada akhirnya menyebabkan anak tidak memahami apa yang dipelajarinya. Oleh karena itu, peneliti tertarik untuk membuat suatu media yang dapat menstimulasi kemampuan membaca permulaan anak dengan melakukan penelitian yang berjudul "Pengembangan Media Big Book untuk Menstimulasi Kemampuan Membaca Permulaan Anak Kelompok B PAUD Tanwirul Qulub Tahun Ajaran 2016/2017’.

\section{B. KAJIAN TEORI}

\section{Membaca Permulaan}

Pada masa usia dini, kegiatan membaca dikenal dengan istilah membaca permulaan. Membaca permulaan menurut Susanto (2011: 83) adalah membaca yang diajarkan secara terprogram kepada anak prasekolah. Program ini merupakan perhatian pada perkataanperkataan utuh, bermakna dalam konteks pribadi anak, bahan-bahan yang diberikan melalui permainan dan kegiatan yang menarik sebagai perantara pembelajaran.

Menurut Efal dalam Dhieni (2009: 5), Perkembangan dasar kemampuan membaca pada anak usia 4-6 tahun berlangsung dalam lima tahap yakni:

a. Tahap Fantasi (Magical Stage)

Pada tahap ini anak mulai belajar menggunakan buku. Anak mulai berpikir bahwa buku itu penting dengan cara membolak-balik buku. Kadang anak juga suka membawa-bawa buku kesukaannya.

b. Tahap Pembetukan Konsep Diri (Self Concept Stage)

Anak memandang dirinya sebagai pembaca dan mulai melibatkan dirinya dalam kegiatan membaca, pura-pura membaca buku, memberi makna pada gambar atau pengalaman sebelumnya dengan buku, menggunakan bahasa buku meskipun tidak cocok dengan tulisan.

c. Tahap Membaca Gambar (Bridging Reading Stage)

Anak menyadari cetakan yang tampak dan mulai dapat menemukan kata yang sudah dikenal, dapat mengungkapkan kata-kata yang memiliki makna dengan dirinya, dapat mengulang kembali cerita yang tertulis, dapat mengenal cetakan kata dari puisi atau lagu yang dikenalnya serta sudah menghafal abjad.

d. Tahap Pengenalan Bacaan (Take-off Reader Stage) 
Anak mulai menggunakan tiga sistem isyarat (graphoponic, semantic dan syntactic) secara bersama-sama. Anak mulai tertarik pada bacaan dan mulai membaca tanda-tanda yang ada di lingkungan seperti membaca kardus susu, pasta gigi dan lain-lain.

e. Tahap Membaca Lancar (Independent Reader Stage)

Anak dapat membaca berbagai jenis buku secara bebas, menyusun pengertian dari tanda, pengalaman dan isyarat yang dikenalnya, dapat membuat perkiraan bahan-bahan bacaan. Bahan-bahan yang berhubungan secara langsung dengan pengalaman anak semakin mudah dibaca.

Terdapat dua pendekatan yang dapat digunakan dalam mengajarkan anak membaca, yaitu :

a. $\quad$ Pendekatan bahasa secara menyeluruh (whole-language approach)

Santrock (2007: 364) mengemukakan bahwa pendekatan bahasa secara menyeluruh menekankan bahwa pelajaran membaca seharusnya paralel dengan pembelajaran bahasa alami anak. Materi-materi membaca sebaiknya utuh dan bermakna. Artinya, anak-anak sebaiknya diberikan materi dalam bentuk lengkap, seperti cerita-cerita, puisi-puisi, sehingga mereka dapat memahami fungsi komunikatif bahasa.

b. Pendekatan keahlian dasar dan fonik (basic-skills-and-phonics)

Menurut Cunningham dalam Santrock (2007: 362), pendekatan keahlian dasar dan fonik menekankan bahwa pelajaran membaca seharusnya mengajarkan fonik dan aturan-aturan dasarnya dalam menerjemahkan simbol-simbol ke dalam bunyi. Menurut pendekatan ini, anak seharusnya mendapat materi-materi bacaan yang rumit (seperti buku dan puisi) hanya setelah mereka memahami aturan-aturan korespondensi yang menghubungkan fonem-fonem lisan dengan huruf-huruf alfabet yang mewakili fonem tersebut (Lane dan Pullen dalam Santrock, 2007: 364).

Pembelajaran membaca permulaan pada anak usia dini harus memperhatikan prinsipprinsip pendidikan anak usia dini, Clements dalam Suyadi dan Maulidya (2013: 2) membagi prinsip-prinsip pendidikan anak usia dini ke dalam empat kategori, yaitu: anak sebagai peserta didik aktif, anak sebagai pembelajar sosial emosional, anak sebagai peserta didik independen (penanggung jawab atas kegiatan yang dilakukannya sendiri), dan anak sebagai pembelajar dunia nyata.

Di bawah ini merupakan media yang digunakan dalam pembelajaran membaca permulaan menurut Musfiroh (2008: 26):

a. Media untuk cerita seperti buku besar (big book), buku cerita bergambar.

b. Media untuk imitasi anak berupa label benda, seperti merk, label nama.

c. Media untuk latihan kesadaran fonemik, meliputi: (1) huruf lepas untuk bermain tukar huruf (sound matching), (2) mengisolasi huruf dari kata (sound isolating), (3) mencampur huruf (sound blending), (4) menambah huruf atau bunyi pada silabel atau kata (sound addition \& subtitution), (5) mensegmentasikan kata ke dalam suku kata, dan suku kata dalam bunyi (sound segmentation).

d. Media untuk elaborasi dan permainan seperti huruf lepas tiga dimensi, kotak huruf pasanglepas, kartu huruf, kartu suku kata, kartu kata.

e. Media untuk imersi pajangan, seperti media untuk jadwal, nama anak, nama hari, nama bulan, label benda di kelas, gambar atau foto, kartu gambar-kata- huruf.

Jamaris (2006: 53) mengemukakan bahwa karakteristik kemampuan dasar membaca anak usia Taman Kanak-kanak antara lain:

a. Kemampuan dalam melakukan koordinasi gerakan visual dan koordinasi gerakan motorik. Gerakan ini secara khusus dapat dilihat pada waktu anak menggerakan bola matanya bersamaan dengan tangan dalam membalik buku gambar atau buku lainnya. 
b. Kemampuan dasar membaca dapat dilihat dari kemampuan anak tersebut dalam melakukan diskriminasi secara visual. Kemampuan ini sebagai dasar untuk dapat membedakan bentukbentuk huruf.

c. Kemampuan dalam kosa kata. Anak usia Taman Kanak-kanak telah memiliki kosa kata yang cukup luas.

d. Kemampuan diskriminasi auditoria atau kemampuan membedakan suara yang didengar. Kemampuan ini berguna untuk membedakan suara atau bunyi huruf. Kemampuan dasar membaca ini merupakan fondasi yang melandasi pengembangan kemampuan membaca.

Kemampuan membaca permulaan anak dipengaruhi oleh berbagai hal, Tampubolon dalam Dhieni (2009: 19) membagi faktor itu menjadi dua, yaitu faktor endogen dan eksogen. Faktor endogen adalah faktor yang berkembang baik secara biologis, maupun psikologis, dan linguistik yang timbul dari diri anak. Sedang, faktor eksogen adalah faktor lingkungan. Kedua faktor ini saling terkait dan mempengaruhi secara bersamaan.

\section{Media Big Book}

Big book merupakan buku cerita yang berkarakteristik khusus yang dibesarkan, baik teks maupun gambarnya, sehingga memungkinkan terjadinya kegiatan membaca bersama antara guru dan murid. Buku ini mempunyai karakteristik khusus seperti penuh warna-warni, memiliki kata yang dapat diulang-ulang, mempunyai alur cerita yang mudah ditebak, dan memiliki pola teks yang sederhana (Karges dalam Solehuddin, dkk. 2008:7). Big Book adalah buku bacaan yang memiliki ukuran, tulisan, dan gambar yang besar. Ukuran Big Book harus mempertimbangkan segi keterbacaan seluruh siswa di kelas.

Menurut Karges-Bone dalam United States Agent International Development (2014: 53), agar pembelajaran bahasa dapat lebih efektif dan berhasil, sebuah big book sebaiknya memiliki ciri-ciri berikut ini.
a. Cerita singkat (10-15 halaman)
b. Pola kalimat jelas
c. Gambar memiliki makna
d. Jenis dan ukuran huruf jelas terbaca
e. Jalan cerita mudah dipahami

United States Agent International Development (2014: 54) menyatakan penggunaan big book dalam pembelajaran membaca memiliki beberapa tujuan, di antaranya adalah berikut ini.
a. Memberi pengalaman membaca
b. Membantu siswa untuk memahami buku
c. Mengenalkan berbagai jenis bahan membaca kepada siswa
d. Memberi peluang kepada guru memberi contoh bacaan yang baik
e. Melibatkan siswa secara aktif dalam pembelajaran
f. Menyediakan contoh teks yang baik untuk digunakan oleh siswa
g. Menggali informasi

Big book adalah suatu bahan belajar yang sekaligus merupakan suatu pendekatan dalam belajar dan mempunyai kelebihan menurut Solehuddin (2008: 7) sebagai berikut :

a. Big book memberikan kesempatan kepada anak untuk terlibat dalam situasi nyata dengan cara yang tidak menakutkan. Dengan membaca big book bersama-sama di depan kelas, anak-anak akan memperoleh pengalaman membaca yang sebenarnya tanpa merasa takut salah.

b. Big book memungkinkan semua anak melihat tulisan yang sama manakala guru membaca tulisan tersebut. Ukurannya yang besar membuat anak dapat melihat tulisan dalam big book yang sedang dibaca oleh guru mereka.

c. Penggunaan big book memungkinkan anak-anak secara bersama-sama dan dengan bekerjasama memberi makna kepada tulisan didalamnya. 
d. Big book memberikan kesempatan kepada anak yang lambat dalam membaca untuk mengenali tulisan dengan bantuan guru dan teman-teman lainnya. Selain itu, big book membuat guru dan anak berbagi keceriaan dan berbagi kegiatan secara bersama.

e. Big book disukai semua anak termasuk mereka yang lambat dalam membaca karena dengan membaca big book bersama-sama akan timbul keberanian dan kenyakinan dalam diri anak bahwa mereka "sudah bisa" membaca.

f. Penggunaan big book akan mengembangkan kemampuan dasar anak dalam semua aspek bahasa yaitu mendengarkan, berbicara, membaca dan menulis.

g. Belajar dengan big book memberikan pengalaman sosial kepada anak yaitu dalam hal berbagi pengalaman pada saat anak-anak mengomentari gambar dan bacaan big book.

h. Meskipun big book adalah bahan bacaan, namun guru dapat menyelinginya dengan percakapan yang relevan mengenai isi cerita bersama anak sehingga topik bacaan akan semakin berkembang sesuai dengan pengalaman dan daya imajinasi anak.

Selain memiliki keistimewaan berdasarkan paparan sebelumnya, dalam penggunaannya untuk menstmulasi kemampuan membaca permulaan anak, big book juga memiliki kekurangan. Setiawan (2001: 41) menyatakan bahwa penggunaan big book sangat menuntut kreativitas guru. Dengan begitu, keberhasilan big book sangat bergantung pada guru. Guru yang kreatif dalam menciptakan dan menggunakan media big book tentu akan mengasilkan media big book yang baik dan dapat menggunakannya dengan baik pula sehingga kemampuan membaca permulaan anak akan terstimulasi dengan baik, begitu pun sebaliknya.

United States Agent International Development (2014: 56) memaparkan langkah-langkah pembuatan big book yang dilakukan secara manual dan menggunakan alat yang sederhana sebagai berikut:

a. Siapkan kertas minimal berukuran A3 sebanyak 8-10 halaman atau 10-15 halaman, spidol warna, lem, dan kertas HVS.

b. Tentukan sebuah topik cerita.

c. Kembangkan topik cerita menjadi cerita utuh dalam satu atau dua kalimat sesuai dengan level atau jenjang kelas. Tuliskan kalimat singkat di atas kertas HVS dengan cara: kertas HVS dipotong menjadi empat bagian memanjang, tulis menggunakan spidol besar (spidol whiteboard) setiap kalimat dengan ukuran yang sama di atas kertas berukuran 1/4 kertas HVS tersebut, tuliskan kalimat dengan huruf-huruf alfabetis yang tepat sesuai dengan kaidah. Tempelkan setiap kalimat tersebut di halaman yang sesuai dengan rencana awal.

d. Siapkan gambar ilustrasi untuk setiap halaman sesuai dengan isi cerita. Gambar ilustrasi dapat dibuat atau diambil dari sumber yang sudah ada.

e. Tentukan judul yang sesuai dengan big book. Tentukan pula gambar ilustrasi yang menarik dan sesuai dengan judul, dan tulislah nama penulisnya.

Adapun prosedur pelaksanaan penggunaan media big book adalah sebagai berikut:

a. Kegiatan pra-membaca

1) Guru memperlihatkan sampul depan serta mengajak anak mengomentari gambar yang ada pada sampul.

2) Guru membacakan judul dan nama pengarang

3) Guru bertanya kepada anak tentang kemungkinan isi cerita berdasarkan pada judul dan ilustrasi sampul.

b. Kegiatan membaca cerita secara utuh

1) Guru membacakan cerita secara berkesinambungan dari halaman pertama sampai terakhir.

2) Guru menunjuk tulisan dengan menggunakan tangan atau alat penunjuk supaya anak dapat mengikuti dan mengetahui tulisan mana yang sedang mereka baca.

c. Kegiatan pengulangan membaca 
1) Guru membaca ulang halaman demi halaman dengan penuh semangat, bergairah, dan hidup.

2) Guru menunjuk kata-kata dan meminta anak untuk berkomentar.

3) Guru berhenti membaca sejenak untuk memberikan kesempatan kepada anak menebak kata selanjutnya dan meramalkan peristiwa yang akan terjadi.

d. Kegiatan setelah membaca pengulangan

1) Guru mendiskusikan kata kunci dalam teks dan membantu anak menghubungkan konsep yang satu dengan yang lain

2) Guru membaca ulang cerita secara bersama-sama.

e. Kegiatan tindak lanjut

1) Guru mengajak anak memperhatikan pada gambar dan pola kata pada teks.

2) Guru memberikan kesempatan kepada anak untuk membaca sendiri.

\section{METODE PENELITIAN}

Jenis penelitian yang digunakan dalam penelitian ini adalah penelitian dan pengembangan. Sugiyono (2015: 407) menyatakan bahwa metode penelitian dan pengembangan atau dalam bahasa Inggrisnya Research and Development adalah metode penelitian yang digunakan untuk menghasilkan produk tertentu, dan menguji keefektifan poduk tersebut.

Menurut Borg dan Gall dalam Sukmadinata (2013: 169) ada sepuluh langkah pelaksanaan strategi penelitian dan pengembangan yaitu: (1) penelitian dan pengumpulan data (research and information collecting); (2) perencanaan (planning); (3) pengembangan draf produk (develop preliminary form of product); (4) uji coba lapangan awal (preliminary field testing); (5) merevisi hasil uji coba (main product revision); (6) uji coba lapangan (main field testing); (7) penyempurnaan produk hasil uji lapangan (operasional field testing), (8) uji pelaksanaan lapangan (operasional field testing), (9) penyempurnaan produk akhir (final product revision); dan (10) diseminasi dan implementasi (dissemination and implemantation). Selanjutnya Borg \& Gall (dalam Emzir, 2013: 271) menyatakan bahwa dimungkinkan untuk membatasi penelitian dalam skala kecil, termasuk membatasi langkah penelitian.

Berdasarkan uraian di atas, peneliti melakukan penyederhanaan dan pembatasan menjadi empat tahapan. Tahapan-tahapan tersebut adalah sebagai berikut:

a. Tahap pengumpulan data awal

Pada tahap ini peneliti melakukan studi lapangan dan studi pustaka untuk memperoleh informasi mengenai pembelajaran membaca permulaan di PAUD Tanwirul Qulub dan memperoleh teori-teori yang relevan dengan variabel yang akan diteliti.

b. Tahap perencanaan

Pada tahap ini peneliti membuat desain awal media big book dan membuat instrumen penelitian.

c. Tahap pengembangan

Pada tahap ini peneliti menentukan cerita dan ilustrasi yang akan dimuat dalam media big book.

d. Tahap validasi dan uji coba

Pada tahap ini produk awal media big book divalidasi oleh dua orang ahli dan diujicobakan pada anak kelompok B PAUD Tanwirul Qulub. Uji coba dilakukan sebanyak 3 tahap, yakni tahap pengembangan 1, tahap pengembangan 2, dan tahap pengembangan 3 . Pada setiap tahap pengembangan dilakukan evaluasi untuk menyempurnakan media big book.

Penelitian ini dikatakan berhasil apabila:

1. Media big book yang dihasilkan dinyatakan layak oleh kedua ahli dengan perolehan persentase kelayakan produk minimal $75 \%$ berdasarkan hasil validasi media. 
2. Media big book yang dihasilkan berhasil menstimulasi kemampuan membaca permulaan anak dengan rata-rata persentase kemampuan membaca anak minimal $75 \%$ setelah 3 tahapuji coba.

3. Guru dapat melaksanakan pembelajaran dengan baik menggunakan media big book dengan persentase rata-rata $75 \%$.

Instrument yang digunakan dalam penelitian ini berupa lembar uji produk media big book, lembar observasi kemampuan membaca permulaan anak kelompok B, dan lembar observasi aktivitas guru dalam pembelajaran.

\section{HASIL PENELITIAN DAN PEMBAHASAN}

Pada tahap pengumpulan data awal, peneliti melakukan studi lapangan menemukan fakta bahwa pembelajaran membaca permulaan yang diterapkan di PAUD Tanwirul Qulub masih belum optimal. Kemampuan membaca permulaan sebagian besar anak di kelompok B masih tergolong kurang. Salah satu penyebab kurangnya kemampuan membaca permulaan anak adalah karena kurang bervariasinya media pembelajaran yang digunakan selama ini. Selain studi lapangan, peneliti juga melakukan studi pustaka sehingga peneliti memperoleh teori-teori ahli berkaitan dengan kemampuan membaca permulaan dan media yang dapat menstimulasinya, dalam hal ini peneliti mengkhususkan pada media big book. Teori-teori tersebut kemudian dijadikan refrensi dalam mengembangkan sebuah media big book yang dapat menstimulasi kemampuan membaca permulaan anak kelompok B PAUD Tanwirul Qulub.

Tahap selanjutnya setelah tahap pengumpulan data adalah tahap perencanaan. Pada tahap perencanaan, peneliti menyiapkan desain media big book yang akan dibuat, adapun desain yang peneliti tentukan adalah: 1) Media big book berukuran A3 (420mm x $297 \mathrm{~mm}$ ), 2) Cerita dalam big book mengambil tema Alam Semesta, 3) Pembuatan ilustrasi big book dilakukan dengan menggabungkan dan menyunting gambar yang diunduh dari beberapa situs di internet, 4) Media big book berisi 11 halaman, 5) Teks dalam media big book menggunakan font Georgia Belle dengan ukuran 72 point. A3 penulis pilih karena ukuran tersebut sudah cukup besar dan memenuhi standar minimal ukuran sebuah media big book, media big book sengaja dibuat bertemakan alam semesta agar sesuai dengan tema pembelajaran yang sedang berlangsung di sekolah. Selain menyiapkan desain big book, pada tahap ini penulis juga menyiapkan instrumen yang terdiri dari instrumen observasi kemampuan membaca permulaan anak kelompok B, lembar observasi aktivitas guru dalam melaksanakan pembelajaran menggunakan media big book, dan lembar validasi media big book. Peneliti memutuskan untuk menghilangkan satu item dari instrumen observasi kemampuan membaca permulaan anak kelompok B karena dianggap tidak relevan oleh salah satu ahli, sedangkan item-item lainnya sudah relevan dan dapat digunakan dalam penelitian.

Setelah desain ditentukan dan instrumen penelitian divalidasi, tahap selanjutnya adalah pengembangan produk. Adapun langkah-langkah yang peneliti lakukan dalam mengembangkan produk media big book adalah sebagai berikut:

1. Membuat cerita yang akan dimuat dalam media big book

2. Mencari gambar-gambar yang sesuai dengan cerita untuk dijadikan ilustrasi dalam media big book

3. Menggabungkan dan menyunting gambar yang sudah dikumpulkan kemudian menambahkan teks sesuai cerita yang sudah ditentukan menggunakan aplikasi CorelDraw

4. Mencetak media big book

Setelah media big book selesai dibuat, media divalidasi dan dari validasi media tersebut, media big book dinyatakan layak oleh kedua ahli dengan memperoleh rata-rata persentase kelayakan sebesar 82,5\% dan masuk kriteria baik dan sudah memenuhi salah satu indikator keberhasilan dari penelitian ini. Pada tahap validasi media, kedua ahli memberikan saran untuk 
menambahkan kartu huruf dan gambar yang bisa dibongkar pasang pada bagian akhir media big book untuk memaksimalkan stimulasi terhadap kemampuan membaca permulaan anak. Oleh karena itu, dilakukan penambahan pada media big book dari produk awal yang dibuat, sehingga media big book yang akan diujicobakan memiliki ciri-ciri sebagai berikut: 1) Media big book berukuran A3 (420mm x $297 \mathrm{~mm})$, 2) Cerita dalam media big book mengambil tema Alam Semesta, 3) Pembuatan ilustrasi media big book dilakukan dengan menggabungkan dan menyunting gambar yang diunduh dari beberapa situs di internet, 4) Media big book berisi 11 halaman, 5) Teks dalam media big book menggunakan font Georgia Belle dengan ukuran 72 point, 6) pada bagian akhir media big book terdapat kartu kata dan gambar yang bisa dibongkar pasang.

Pada tahap pengembangan 1, hasil observasi menunjukkan bahwa aktivitas guru dalam pembelajaran menggunakan media big book sudah cukup baik dengan persentase 73,6\%, namun penggunaan media big book belum maksimal dalam menstimulasi kemampuan membaca permulaan anak, dapat dilihat dari sangat kurangnya kemampuan membaca permulaan anak dengan persentase $54,3 \%$.

Kekurangan-kekurangan pada tahap pengembangan 1 dijadikan sebagai pembelajaran oleh guru agar tahap pengembangan 2 dapat berjalan dengan lebih baik dan kemampuan anak dapat berkembang dengan baik. Hal-hal yang dilakukan untuk memperbaiki kekurangan-kekurangan pada tahap pengembangan 1 antara lain:

1. Cerita dalam media big book dibuat lebih singkat

2. Cerita dalam media big book menggunakan kata-kata yang mudah dipahami oleh anak

3. Gambar yang digunakan lebih sederhana namun bisa mengilustrasikan cerita

4. Menyiapkan kelas dan mengatur posisi duduk anak

5. Guru menyiapkan lagu dan tepukan untuk membuka pelajaran agar anak lebih bersemangat dan memperkenalkan media big book serta aturan menggunakan media big book

6. Guru mengatur tempo saat membaca cerita agar tidak terlalu cepat

Setelah memperbaiki kekurangan-kekurangan pada tahap pengembangan 1, tahap pengembangan 2 berjalan dengan lebih baik. Pada tahap pengembangan 2, kemampuan membaca permulaan anak kelompok B berhasil terstimulasi dengan cukup baik dengan ratarata persentase perkembangan kemampuan membaca permulaan anak 74,4\%, meningkat 20,1\% dari tahap pengembangan 1. Aktivitas guru dalam melaksanakan pembelajaran menggunakan media big book juga mengalami peningkatan dan masuk kriteria baik dengan rata-rata persentase $83,3 \%$, capaian tersebut sudah memenuhi salah satu indikator keberhasilan dari penelitian ini. Hal-hal yang dilakukan untuk memperbaiki kekurangan-kekurangan pada tahap pengembangan 1 antara lain:

1. Guru memberikan perhatian lebih pada beberapa anak agar fokus dalam pembelajaran

2. Guru memperbanyak diskusi membahas huruf-huruf dan kata dalam kalimat dengan anak

3. Guru lebih banyak memberikan pujian agar anak lebih termotivasi

Selanjutnya, pada tahap pengembangan 3 pembelajaran dilakukan untuk memaksimalkan aktivitas guru dalam pembelajaran dan stimulasi terhadap kemampuan membaca permulaan anak menggunakan media big book. Pada tahap pengembangan 3, persentase rata-rata kemampuan membaca permulaan anak juga berhasil terstimulasi dengan baik dan mengalami peningkatan 10,2\% dari tahap pengembangan 2 dan masuk kategori baik dengan rata-rata persentase 84,6\%. Aktivitas guru dalam pembelajaran menggunakan media big book juga berhasil dimaksimalkan menjadi sangat baik pada tahap ini dengan memperoleh persentase $100 \%$.

Uraian di atas menunjukkan bahwa media big book yang dikembangkan layak digunakan dalam pembelajaran dan dapat menstimulasi kemampuan membaca permulaan anak. Berikut adalah ciri media big book yang baik dalam menstimulasi kemampuan membaca permulaan anak: 
1. Media big book berukuran besar (miniman A3)

2. Cerita singkat (8-15 halaman)

3. Kalimat yang terdapat pada setiap halaman tidak terlalu panjang

4. Cerita menggunakan kata-kata yang mudah dipahami oleh anak

5. Gambar yang digunakan dapat mengilustrasikan cerita di dalam media big book

6. Tulisan yang terdapat dalam media big book dapat terlihat oleh anak

Selain media big book, aktivitas guru dalam pembelajaran menggunakan media big book juga penting dalam menstimulasi kemampuan membaca permulaan anak. Beberapa hal yang harus diperhatikan guru saat melaksanakan pembelajaran menggunakan media big book agar dapat menstimulasi kemampuan membaca permulaan anak adalah sebagai berikut:

1. Mengatur posisi duduk anak agar anak merasa nyaman dan kelas tetap kondusif selama pembelajaran berlangsung

2. Membuka pembelajaran dengan menyenangkan, dalam hal ini guru dapat menggunakan nyanyian atau tepukan yang sesuai dengan cerita dalam media big book

3. Mengenalkan media big book dan langkah-langkah penggunaannya pada anak

4. Memperhatikan tempo pada saat membaca cerita

5. Memberikan kesempatan pada anak untuk membaca sendiri dan memahami tulisan dalam media big book serta pelafalannya.

\section{E. SIMPULAN}

Berdasarkan hasil penelitian yang telah dilakukan, dapat disimpulkan bahwa media big book yang dihasilkan dapat menstimulasi kemampuan membaca permulaan anak kelompok B PAUD Tanwirul Qulub Tahun Ajaran 2016/2017, terbukti dengan:

1. Media big book memiliki kelayakan yang baik untuk digunakan dalam pembelajaran membaca permulaan anak kelompok B dengan perolehan rata-rata persentase $82,5 \%$ berdasarkan validasi media oleh dua orang ahli. Media big book yang dihasilkan memiliki ciri-ciri: 1) Berukuran A3 (440 mm x $297 \mathrm{~mm}$ ), 2) Terdiri dari 11 halaman, 3) Memuat cerita sederhana bertemakan Alam Semesta, 4) Memiliki ilustrasi sesuai dengan cerita, 5) Teks pada media big book mudah terbaca dengan menggunakan font Georgia Belle berukuran 72 point, dan 6) Dilengkapi dengan kartu huruf dan gambar pada bagian akhir

2. Penggunaan media big book berhasil menstimulasi kemampuan membaca permulaan anak kelompok B PAUD Tanwirul Qulub Tahun Ajaran 2016/2017 dengan baik, terlihat dari peningkatan kemampuan membaca permulaan anak pada setiap tahap pengembangan. Pada tahap pengembangan 1, rata-rata persentase sejumlah 54,3\%. Pada tahap pengembangan 2 , rata-rata persentase sejumlah $74,4 \%$, dan pada tahap pengembangan 3 rata-rata persentase sejumlah $84,6 \%$ dan termasuk kriteria baik.

3. Guru dapat melaksanakan pembelajaran dengan baik menggunakan media big book. Pada tahap pengembangan 1, aktivitas guru dalam pembelajaran memperoleh persentase $73,6 \%$. Pada tahap pengembangan 2, aktivitas guru dalam pembelajaran memperoleh persentase 83,3\%. Pada tahap pengembangan 3 , aktivitas guru dalam pembelajaran memperoleh persentase $100 \%$ dan masuk kriteria sangat baik.

\section{DAFTAR PUSTAKA}

Agung, A. A. Gede. 2010. Evalusi Pendidikan. Singaraja: Undiksha.

Alek \& Achmad. 2010. Bahasa Indonesia untuk Perguruan Tinggi. Jakarta: Kencana Perdana Media Group.

Aqila Darmata Synta. 2015. Peningkatan Keterampilan Membaca Permulaan Melalui Media Big Book Pada Siswa Kelas I SD Negeri Delegan 2 Prambanan Sleman. https://eprints.uny.ac.id. Diakses tanggal 18 Januari 2017.

Dalman. 2013. Keterampilan Membaca. Jakarta: Raja Garafido Persada 
Dhieni, Nurbiana dkk. 2009. Metode Pengembangan Bahasa. Jakarta: Universitas Terbuka

Fahruddin. 2016. Sinopsis Disertasi Pengaruh Metode Pembelajaran dan Kemandirian terhadap Kemampuan Baca-Tulis Permulaan Anak Usia Dini. Jakarta: Universitas Negeri Jakarta

Husnaini, Nani. 2012. Peningkatan Kemampuan Membaca Permulaan melalui Buku Besar. https:// eprints.unj.ac.id. Diakses tanggal 20 April 2017.

Jamaris, Martini. 2006. Perkembangan Dan Pengembangan Anak Usia Taman Kanak-Kanak. Jakarta: PT Gramdia widia Sarana Indonesia

Kustadi, Cecep dan Bambang Sudjipto. 2011. Media Pembelajaran Manual dan Digital. Bogor: Ghalia Indonesia.

Kuwat Listiyawati. 2013. Pengaruh Media Big Book Terhadap Perkembangan Kemampuan Membaca Awal Pada Anak Kelompok A di TK Aisyiyah Pabelan Kartasuro Sukoharjo Tahun Ajaran 2012/2013. https:// eprints.ums.ac.id. Diakses pada tanggal 18 Januari 2017.

Masjidi, Noviar. 2007. Agar Anak Suka Membaca. Yogyakarta: Media Insani.

Musfiroh, Tadkiroatun. 2008. Menumbuhkembangkan Baca Tulis Anak Usia Dini.. http://books.google.co.id/. Diakses pada tanggal 12 Januari 2017.

Nurani, Yuliani. 2013. Konsep Dasar Pendidikan Anak Usia Dini. Jakarta: PT Indeks.

Nurkancana, I Wayan dan Sunartana. 2015. Evaluasi Hasil Belajar. Surabaya.

Peraturan Menteri Pendidikan dan Kebudayaan Republik Indonesia Nomor 137 Tahun 2014 tentang Standar Nasional Pendidikan Anak Usia Dini. 2014. Jakarta.

Rahim, Farida. 2008. Pengajaran Membaca di Sekolah Dasar. Jakarta: Bumi Aksara.

Sanjaya, Wina. 2011. Penelitian Tindakan Kelas. Jakarta: Kencana Media Group.

Seefeldt, Carol. Wasik, Barbara A. 2008. Pendidikan Anak Usia Dini. Jakarta: PT Indek

Setiawan, Denny, dkk. 2001. Belajar Membaca yang Menyenangkan dengan Big Book. Jakarta: Indolatih Manajemen

Solehuddin, dkk. 2009. Pembaharuan Pendidikan TK. Jakarta: Universitas Terbuka.

Sugiyono. 2015. Metode Penelitian Pendidikan. Bandung: Alfabeta.

Suharsimi, Arikunto. 2010. Managemen Penelitian. Jakarta: Rineka Cipta.

Suyadi, Maulidya Ulfah. 2013. Konsep Dasar PAUD. Bandung: PT Remaja Rosdakarya Offset.

Tegeh, I Made. Kirna, I Made. 2010. Metode Penelitian Pengembangan Pendidikan. Singaraja: Universitas Pendidikan Ganesha Singaraja.

United States Agency International Development. Buku Sumber untuk Dosen LPTK: Pembelajaran Literasi di Kelas Awal di LPTK. http://www.prioritaspendidikan.org/id/media/view/detail/297/buku-sumber-untukdosen-lptk--pembelajaran-literasi-di-kelas-awal-di-lptk, Diakses tanggal 18 Januari 2017.

Yuniati. 2014. Peningkatan Keterampilan Membaca Permulaan Melalui Media Big Books Siswa Kelas IB SDN Mangiran Kecamatan Srandakan. https:// eprints.uny.ac.id. Diakses tanggal 18 Januari 2017.

Zubaidah, Enny. 2013. Draf Penulisan Buku Kesulitan Membaca Permulaan pada Anak Diagnosa dan Cara Mengatasinya. https://staff.uny.ac.id. Diakses tanggal 07 September 2016 